\title{
PENINGKATAN KAPASITAS KELEMBAGAAN KELOMPOK TANI DALAM PENGEMBANGAN USAHATANI AGROFORESTRY: Studi Kasus di Desa Cukangkawung, Kecamatan Sodonghilir, Kabupaten Tasikmalaya, Provinsi Jawa Barat

\author{
(Institutional Capacity Building of Farmer Groups in Agroforestry Farming: Case Study in
} Cukangkawung Village, Sodonghilir Subditsrict, Tasikmalaya District, West Java Province)
}

\author{
Idin Saepudin Ruhimat \\ Balai Penelitian dan Pengembangan Teknologi Agroforestry, \\ Jalan Ciamis Banjar KM 4 Ciamis, Jawa Barat Indonesia \\ Email: idintea@yahoo.co.id
}

Diterima 21 Desember 2016, direvisi 27 Maret 2017, disetujui 29 Maret 2017

\begin{abstract}
This study aims to determine the factors that influence the institutional capacity of farmer groups, and to formulate increasing institutional capacity of farmer groups in the agroforestry farming development. Research was conducted in the Cukangkawung Village, Sodonghilir Subdistrict, Tasikmalaya District, West Java Province, from August 2015 to February 2016. Data was analyzed by using Structural Equation Modelling approach (SEM) of SmartPls program. The results showed that (1) the institutional capacity of farmer group was directly influenced by dynamism level and members 'participation and indirectly influenced by role of the leader, capacity of members, extension role, external support, and characteristics of farmers, and (2) efforts to increase institutional capacity of farmer group can be done through increasing dynamism and participation of members in the activities of farmer groups.
\end{abstract}

Keywords: Agroforestry; farmer group; structural analysis; West Java, Indonesia.

\begin{abstract}
ABSTRAK
Penelitian ini bertujuan untuk mengetahui faktor-faktor yang berpengaruh terhadap kapasitas kelembagaan kelompok tani, dan merumuskan usaha peningkatan kapasitas kelembagaan kelompok tani dalam pengembangan usahatani agroforestry. Penelitian di laksanakan di Desa Cukangkawung, Kecamatan Sodonghilir, Kabupaten Tasikmalaya, Provinsi Jawa Barat selama enam bulan, dari bulan Agustus 2015 sampai dengan Pebruari 2016. Data dianalisis dengan Structural Equation Modelling (SEM) menggunakan program SmartPls. Hasil penelitian menunjukkan (1) kapasitas kelembagaan kelompok tani dipengaruhi secara langsung oleh tingkat kedinamisan dan partisipasi anggota serta secara tidak langsung oleh peran pemimpin, kapasitas anggota, peran penyuluh, dukungan pihak luar, dan karakteristik petani, dan (2) usaha peningkatan kapasitas kelembagaan kelompok tani dapat dilakukan melalui peningkatan kedinamisan dan partisipasi anggota dalam kegiatan kelompok tani.
\end{abstract}

Kata kunci: Agroforestry; kelompok tani; analisis struktural; Jawa Barat, Indonesia. 


\section{PENDAHULUAN}

Agroforestry merupakan salah satu bentuk pemanfaatan lahan secara berkelanjutan yang mengombinasikan tanaman kehutanan dengan tanaman pertanian dan atau ternak pada suatu areal yang sama dengan tujuan untuk meningkatkan nilai sosial, ekonomi, dan ekologi usahatani (Butarbutar, 2012; Harun, 2011; Hiola, 2011; Mayrowani \& Ashari, 2011; Sumiati, 2011). Besarnya manfaat yang diperoleh dari usahatani agroforestry telah mendorong para pihak untuk menjadikan sistem agroforestry sebagai salah satu program pengembangan usahatani secara berkelanjutan (Rambey, 2011; Umiyati, 2015).

Program pengembangan usahatani berkelanjutan dengan sistem agroforestry telah dilakukan pada lahan milik masyarakat di Kabupaten Tasikmalaya, salah satunya di Desa Cukangkawung, melalui beberapa kegiatan seperti pembuatan hutan rakyat pola agroforestry, dan pengayaan tanaman perkebunan (BP3K, 2015). Akan tetapi, pengembangan usahatani agroforestry di beberapa daerah masih belum terlaksana secara optimal. Rendahnya peran kelompok tani merupakan salah satu penyebab ketidakoptimalan pengembangan usahatani agroforestry sebagaimana dikemukakan dalam penelitian yang dilakukan oleh Puspitodjati et al. (2013) di wilayah Daerah Aliran Sungai (DAS) Cimuntur dan Kuswantoro et al. (2014) di wilayah DAS Cikawung.

Rendahnya peran kelompok tani dalam berbagai program pengembangan usahatani yang dilakukan pemerintah di Indonesia disebabkan masih rendahnya tingkat kapasitas kelembagaan kelompok tani (Syahyuti, 2011). Oleh karena itu, peningkatan kapasitas kelembagaan kelompok tani diharapkan menjadi salah satu solusi dalam mengoptimalkan peran kelompok tani dalam pengembangan usahatani agroforestry.

Hasil penelitian dan pendapat yang telah dikemukakan di atas, hanya mengemukakan tentang kapasitas kelembagaan kelompok tani dan pengaruhnyaterhadap peran kelompoktani dalam pengembangan usahatani, tetapi tidak menjelaskan secara terukur faktor-faktor yang berpengaruh terhadap kapasitas kelembagaan kelompok tani dalam pengembangan usahatani agroforestry. Padahal, pengetahuan tentang faktor-faktor yang berpengaruh terhadap kapasitas kelembagaan kelompok tani dapat digunakan untuk merumuskan usaha peningkatan kapasitas kelembagaan kelompok tani dalam rangka meningkatkan peran kelompok tani dalam pengembangan usahatani agroforestry.

Berdasarkan uraian di atas, maka penelitian ini bertujuan untuk mengetahui faktorfaktor yang berpengaruh terhadap kapasitas kelembagaan kelompok tani, dan merumuskan usaha peningkatan kapasitas kelembagan kelompok tani dalam pengembangan usahatani agroforestry. Hasil penelitian ini diharapkan menjadi bahan pertimbangan untuk para pengambil kebijakan, yaitu Pemerintah Kabupaten Tasikmalaya, Pemerintah Provinsi Jawa Barat, dan pemerintah pusat, dalam pengembangan usahatani agroforestry di Desa Cukangkawung.

\section{METODE PENELITIAN}

\section{A. Waktu dan Lokasi Penelitian}

Penelitian dilaksanakan mulai bulan Agustus 2015 sampai dengan Pebruari 2016 di Desa Cukangkawung, Kecamatan Sodonghilir, Kabupaten Tasikmalaya, Provinsi Jawa Barat. Peta lokasi penelitian disajikan pada Gambar 1. Pemilihan Desa Cukangkawung sebagai lokasi penelitian dilakukan secara purposive dengan pertimbangan Desa Cukangkawung merupakan salah satu wilayah pengembangan usahatani agroforestry di Kabupaten Tasikmalaya.

\section{B. Populasi dan Sampel Penelitian}

Populasi dalam penelitian ini adalah seluruh petani yang menjadi anggota kelompok tani di wilayah administrasi Desa Cukangkawung yang berjumlah 507 orang. Mereka tergabung 


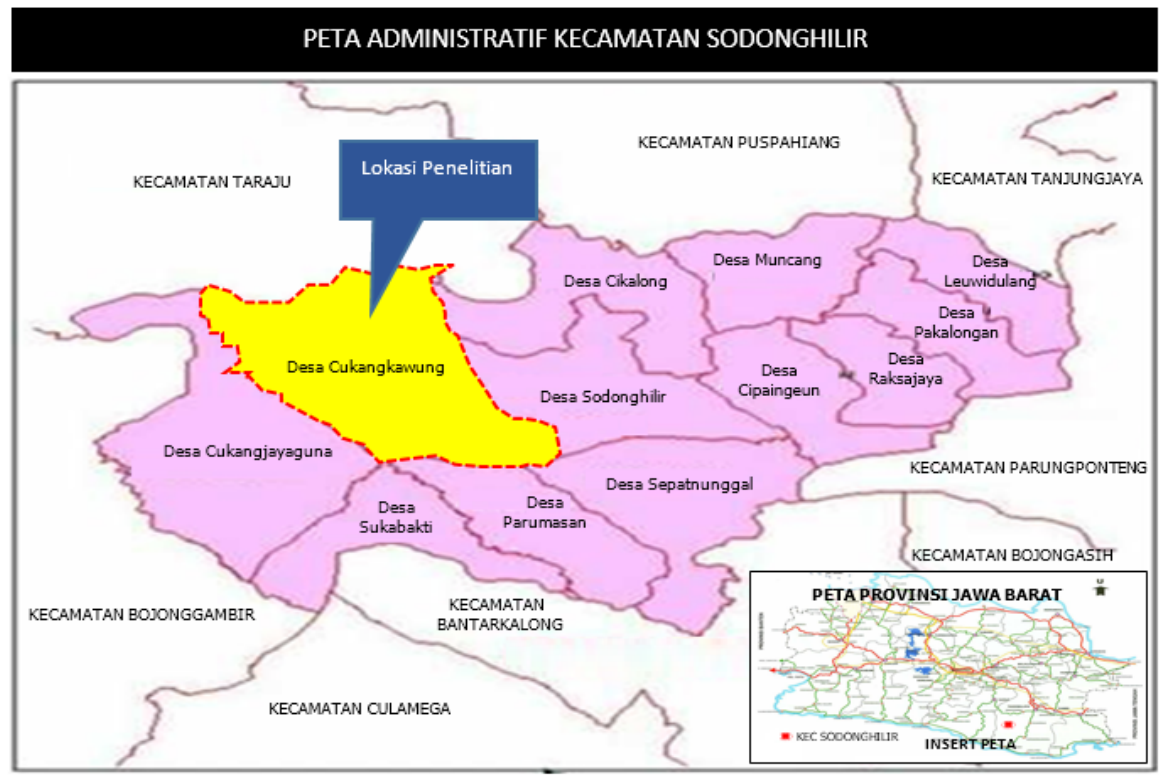

Sumber (Source) : Badan Pusat Statistik, 2014.

Gambar 1. Peta lokasi penelitian

Figure 1. Research site map

dalam 11 kelompok tani. Penentuan jumlah anggota kelompok tani yang dijadikan sebagai sampel dalam penelitian dihitung dengan menggunakan rumus Slovin (Mun'im, 2012; Wiyono, 2011), yaitu

$$
n=\text { ukuran sampel }
$$

$$
n=\frac{N}{1+N e^{2}}
$$

$$
\begin{aligned}
N= & \text { populasi } \\
e= & \text { margin of error (pada penelitian ini } \\
& \text { ditetapkan } 0,05)
\end{aligned}
$$

Berdasarkan perhitungan dengan rumus Slovin, 224 orang dijadikan sebagai sampel penelitian. Penarikan sampel dalam populasi dilakukan dengan menggunakan teknik penarikan sampel bertahap (multistage sampling) dengan tahapan sebagai berikut: (1) memilih seluruh kelompok tani yang terdapat di Desa Cukangkawung sebagai sampel penelitian dengan menggunakan metode sensus, (2) menentukan jumlah sampel penelitian pada masing-masing kelompok tani dengan menggunakan metode proposionate random sampling yaitu memilih sampel penelitian secara acak dan proporsional sesuai dengan jumlah anggota pada setiap kelompok tani. Alokasi proporsional jumlah sampel pada masing-masing kelompok tani ditentukan dengan menggunakan rumus (Mun'im, 2012; Ruhimat, 2015):

$$
n i=\frac{N i}{N} n
$$

dimana: $n i=$ jumlah sampel dalam stratum $\mathrm{i}$, $n=$ jumlah sampel seluruhnya, $N i=$ jumlah populasi dalam stratum i, $N=$ jumlah populasi seluruhnya

Berdasarkan perhitungan tersebut maka diperoleh jumlah sampel untuk setiap kelompok tani seperti ditunjukkan pada pada Tabel 1, dan (3) memilih nama anggota kelompok tani yang dijadikan sampel penelitian. Pemilihan dilakukan secara acak (random) melalui sistem pengundian dengan tujuan untuk memberikan kesempatan yang sama kepada semua anggota kelompok. 
Tabel 1. Sebaran jumlah responden pada setiap kelompok tani

Table 1. The number of respondents distribution in each farmers group

\begin{tabular}{rlcc}
\hline $\begin{array}{l}\text { No } \\
(\text { No. })\end{array}$ & Nama Kelompok Tani & Jumlah Anggota \\
(Name of Farmers Group $)$ & Jumber of Member $)$ & $\begin{array}{l}\text { Jumlah Sampel } \\
\text { (Number of Sample })\end{array}$ \\
\hline 1 & Tani Jaya & 40 & 18 \\
2 & Kawunghegar & 31 & 14 \\
3 & Sari Tani & 29 & 13 \\
4 & Sinar Mukti & 35 & 15 \\
5 & Sabanda & 32 & 14 \\
6 & Mekarwangi 1 & 30 & 13 \\
7 & Mekarwangi 2 & 31 & 14 \\
8 & Sahate 1 & 36 & 16 \\
9 & Sahate 2 & 43 & 19 \\
10 & Sahate 3 & 56 & 25 \\
11 & Sukaati & 43 & 19 \\
12 & Sabilul Hidayah & 28 & 12 \\
13 & Mutiara tani & 43 & 19 \\
14 & Candra Jaya & 30 & 13 \\
\hline
\end{tabular}

Sumber (Source) : Data primer (Primary data), 2016

\section{Teknik Pengumpulan dan Analisis Data}

Data yang dikumpulkan dalam penelitian ini terdiri dari data sekunder dan data primer. Data sekunder dikumpulkan melalui studi literatur dan studi dokumentasi dari berbagai data yang diterbitkan oleh instansi terkait seperti Badan Pusat Statistik (BPS) Kabupaten Tasikmalaya, Dinas Kehutanan dan Perkebunan (Dishutbun) Kabupaten Tasikmalaya, Pemerintahan Desa Cukangkawung, Pemerintahan Kecamatan Sodonghilir, dan sebagainya. Data primer dikumpulkan melalui wawancara mendalam (in-depth interview), pengamatan langsung di lokasi penelitian (observation), diskusi kelompok terarah/focus group discussion (FGD), dan survei menggunakan kuisioner. Kuisioner penelitian bersifat tertutup yang disusun menggunakan skala likert (Likert Summated Rating).

Data dianalisis dengan Structural Equation
Modellling (SEM) menggunakan program SmartPLs. Analisis SEM merupakan analisis struktural yang menggabungkan analisis faktor dan analisis regresi dengan tujuan untuk menganalisis model hubungan, baik antar indikator dalam variabel maupun antar variabel penelitian (Ruhimat, 2015; Santoso, 2012; Wiyono, 2011).

Analisis SEM dengan SmartPls menghasilkan beberapa luaran diantaranya variabel laten (endogen dan eksogen), indikator, nilai koefisien jalur (path coefficient), nilai koefisien determinasi (determinastic coefficient), nilai koefisien korelasi (correlation coefficient) dan sifat pengaruh antar variabel (pengaruh langsung atau dirrect effect, dan pengaruh tidak langsung atau indirrect effect). Model luaran (output) hasil analisis SEM dengan SmartPls dapat dilihat pada Gambar 2.

Variabel laten merupakan variabel 


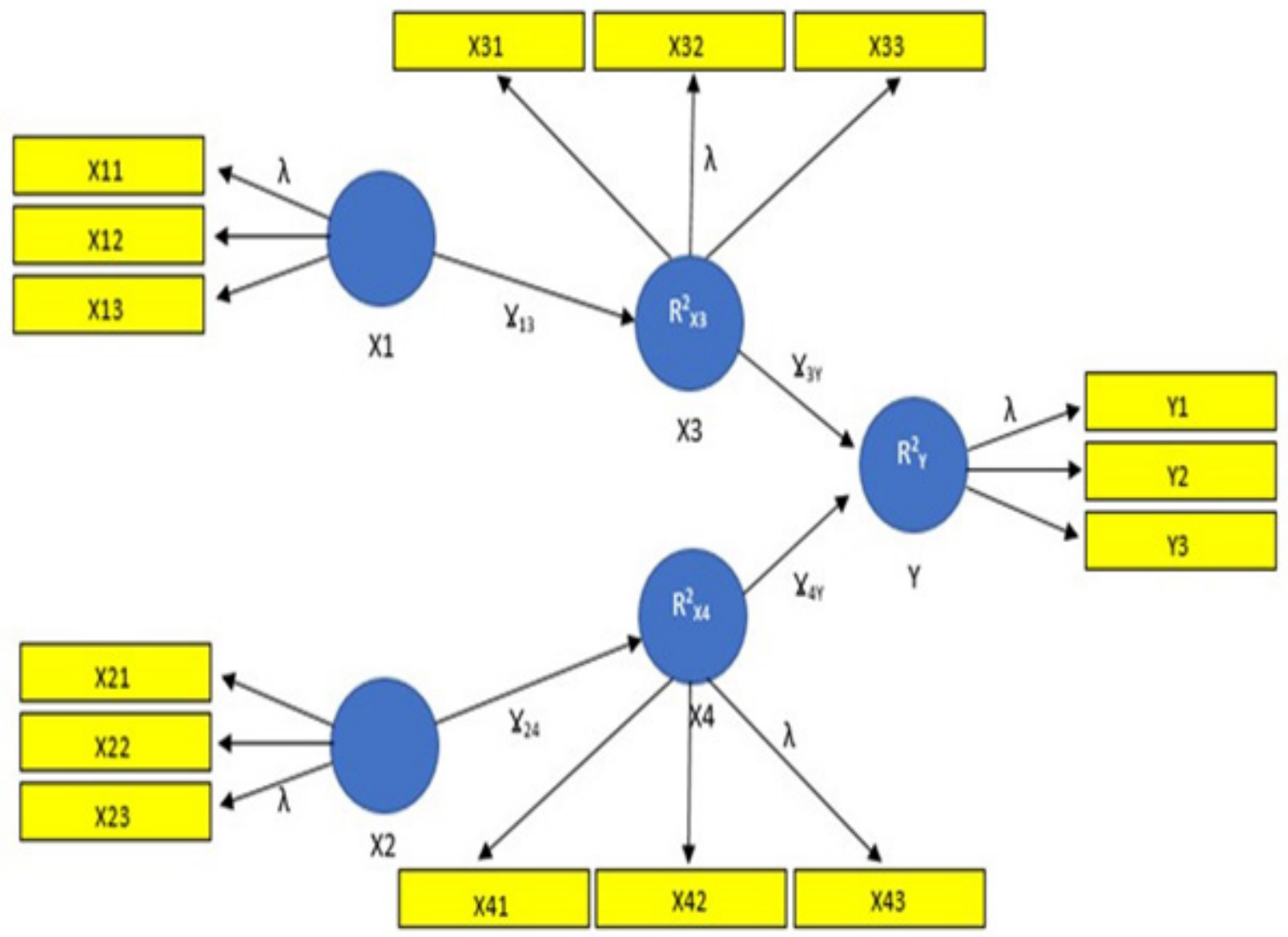

Sumber (Source) : Dachlan, 2016

Gambar 2. Model luaran program SmartPls

Figure 2. Output of SmartPls program

penelitian yang tidak dapat diukur secara langsung (undimensional). Pengukuran variabel penelitian dilakukan melalui indikator-indikator yang menyusun variabel tersebut. Variabel penelitian terdiri dari variabel laten eksogen dan endogen. Variabel laten eksogen merupakan variabel bebas (independent) yang memengaruhi variabel terikat (dependen), sedangkan variabel laten endogen merupakan variabel terikat yang dipengaruhi oleh satu atau lebih variabel bebas. Pada luaran analisis SmartPls (Gambar 2.) variabel laten digambarkan oleh lingkaran berwarna biru yang terdiri dari $\mathrm{X}_{1}, \mathrm{X}_{2}, \mathrm{X}_{3}$, $\mathrm{X}_{4}$, dan $\mathrm{Y}$.

Nilai koefisien jalur (Y) merupakan nilai koefisien regresi terstandar yang menunjukkan besaran pengaruh suatu variabel endogen (variabel bebas) terhadap variabel eksogen (variabel terikat). Nilai koefisien jalur digambarkan dalam bentuk garis yang menghubungkan dua variabel $\left(\mathrm{V}_{13}, \mathrm{Y}_{24}, \mathrm{Y}_{3 \mathrm{Y}}\right.$, dan $\gamma_{4 Y}$ ). Variabel eksogen yang memiliki nilai koefisien jalur lebih besar akan memiliki pengaruh yang lebih besar terhadap variabel endogen dibandingkan variabel eksogen lainnya.

Nilai koefisien determinasi $\left(\mathrm{R}^{2}\right)$ yaitu koefisien yang menjelaskan proporsi dari variabel endogen yang dapat dijelaskan oleh variabel-variabel eksogen yang memengaruhinya (Dachlan, 2014). Nilai koefisien determinasi dalam SmartPls digambarkan oleh angka yang terdapat pada lingkaran berwarna biru $\left(\mathrm{R}^{2}{ }_{\mathrm{X} 3}, \mathrm{R}_{\mathrm{X} 4}^{2}, \mathrm{R}_{\mathrm{Y}}^{2}\right)$.

Nilai koefisien korelasi $(\lambda)$ dalam SmartPls menunjukkan besaran nilai hubungan antara variabel laten dengan indikator-indikator 
penyusunnya yang digambarkan dalam bentuk garis yang menghubungkan variabel laten dan indikatornya.

Pengaruh langsung diartikan sebagai pengaruh dari suatu variabel terhadap variabel lain tanpa harus melalui variabel antara, sedangkan pengaruh tidak langsung mengandung pengertian suatu variabel akan berpengaruh terhadap variabel lain dengan cara memengaruhi variabel antara terlebih dahulu. Pada Gambar 2 pengaruh langsung ditunjukkan oleh pengaruh variabel $X_{1}$ terhadap $\mathrm{X}_{3}, \mathrm{X}_{3}$ terhadap $\mathrm{Y}, \mathrm{X}_{2}$ terhadap $\mathrm{X}_{4}$, dan $\mathrm{X}_{4}$ terhadap $\mathrm{Y}$, sedangkan pengaruh tidak langsung ditunjukan oleh pengaruh variabel $\mathrm{X}_{1}$ terhadap $\mathrm{Y}$ melalui $\mathrm{X}_{3}$, dan $\mathrm{X}_{2}$ terhadap $\mathrm{Y}$ melalui $\mathrm{X}_{4}$.

\section{Variabel Penelitian}

Penelitian ini merupakan penelitian eksplanasi (explanatory research) yang menjelaskan model hubungan kausalitas antar beberapa variabel yang telah ditetapkan dalam penelitian. Variabel-variabel tersebut terdiri dari kapasitas kelembagaan kelompok tani $(\mathrm{Y})$, kedinamisan kelompok tani $\left(\mathrm{X}_{7}\right)$, partisipasi anggota kelompok tani $\left(\mathrm{X}_{6}\right)$, peran kelompok tani $\left(\mathrm{X}_{5}\right)$, kapasitas anggota $\left(\mathrm{X}_{4}\right)$, karakteristik anggota $\left(\mathrm{X}_{3}\right)$, peran pihak luar $\left(\mathrm{X}_{2}\right)$, dan peran penyuluh $\left(\mathrm{X}_{1}\right)$. Adapun definisi, parameter dan kategori pengukuran masing-masing variabel penelitian beserta indikator penyusunnya adalah sebagai berikut (Tabel 2 sampai dengan Tabel 9).

1. Kapasitas kelembagaan kelompok tani (Y) merupakan kemampuan kelompok tani dalam melaksanakan fungsi dan peran yang dimilikinya untuk mencapai tujuan yang telah ditetapkan oleh seluruh anggota kelompok tani (Anantanyu, 2009)

2. Peran penyuluh $\left(\mathrm{X}_{1}\right)$ didefinisikan segala kegiatan yang dilakukan oleh penyuluh dalam mendidik, membimbing, memfasilitasi dan mendampingi petani dalam pengelolaan usaha tani (Yunita, 2011).

3. Peran pihak luar $\left(\mathrm{X}_{2}\right)$ merupakan segala bentuk bantuan, baik materiil maupun non materiil, yang berasal dari luar petani yang memberikan manfaat atau keuntungan bagi petani dalam berusaha tani (Suprayitno, 2011).

4. Karakteristik anggota $\left(\mathrm{X}_{3}\right)$ adalah ciriciri atau sifat-sifat khusus individu yang melekat pada diri seorang petani yang berhubungan dengan semua aspek kehidupan (Suprayitno, 2011).

5. Kapasitas anggota $\left(X_{4}\right)$ merupakan daya yang melekat pada pribadi seorang petani sebagai pelaku utama pengelola sumber daya alam untuk menetapkan tujuan usaha tani dan cara mencapai tujuan pengelolaan hutan rakyat secara tepat (Subagio, 2008).

6. Peran ketua kelompok tani $\left(\mathrm{X}_{5}\right)$ adalah semua bentuk kegiatan ketua kelompok tani sebagai koordinator, inspirator, dan motivator untuk semua anggota kelompok tani yang dipimpinnya (Hermanto \& Swastika, 2011).

7. Partisipasi anggota $\left(\mathrm{X}_{6}\right)$ didefinisikan sebagai keikutsertaan anggota dalam berbagai kegiatan yang dilaksanakan oleh kelompok tani mulai dari perencanaan, pelaksanaan, pemeliharaan hasil, pemanfaatan, sampai dengan proses monitoring evaluasi kegiatan (Anantanyu, 2009)

8. Kedinamisan kelompok tani $\left(\mathrm{X}_{7}\right)$ merupakan kekuatan yang terdapat di dalam atau di lingkungan kelompok tani yang menentukan perilaku anggota dan kelompok yang bersangkutan untuk bertindak dalam mencapai tujuan yang telah ditetapkan bersama (Lestari, 2012)

\section{HASIL DAN PEMBAHASAN}

\section{A. Faktor-faktor yang Berpengaruh Terhadap Kapasitas Kelembagaan Kelompok Tani}

Hasil analisis SEM dengan menggunakan program SmartPls disajikan dalam bentuk model struktural faktor-faktor yang berpengaruh terhadap tingkat kapasitas 
Tabel 2. Indikator, definisi, parameter dan kategori pengukuran kapasitas kelembagaan kelompok tani Table 2. Indicators, definition, parameters and measurement category of institutional capacity of farmer groups

\begin{tabular}{|c|c|c|c|}
\hline Indikator (Indicator) & Definisi (Definition) & $\begin{array}{c}\text { Parameter pengukuran } \\
\text { (Measurement parameter) }\end{array}$ & $\begin{array}{c}\text { Kategori pengukuran } \\
\text { (Measurement } \\
\text { category) }\end{array}$ \\
\hline $\begin{array}{l}\text { Y, Keinovatifan } \\
\text { (Innovation) }\end{array}$ & $\begin{array}{l}\text { Tingkat kemampuan kelompok } \\
\text { tani dalam membangun dan } \\
\text { mengembangkan nilai-nilai seperti } \\
\text { kerja sama, pembagian peran, pola } \\
\text { kewenangan, komitmen anggota, } \\
\text { kualitas sumber daya anggota, } \\
\text { dan teknologi dalam pemecahan } \\
\text { masalah yang dihadapi kelompok } \\
\text { tani (Anantanyu, 2009) }\end{array}$ & $\begin{array}{lcr}\text { Diukur } & \text { berdasarkan } & \text { skor } \\
\text { responden } & \text { terhadap } & \text { tingkat } \\
\text { keinovatifan } & \text { kelembagaan } \\
\text { kelompok } & \text { tani } & \text { dalam } \\
\text { pengembangan } & & \text { usahatani } \\
\text { agroforestry } & & \end{array}$ & $\begin{array}{l}\text { 1. Sangat rendah } \\
\text { 2. Rendah } \\
\text { 3. Sedang } \\
\text { 4. Tinggi } \\
\text { 5. Sangat tinggi }\end{array}$ \\
\hline $\begin{array}{l}\mathrm{Y}_{2 .} \text { Keberlanjutan } \\
\text { (Sustainability) }\end{array}$ & $\begin{array}{l}\text { Tingkat kemampuan kelompok } \\
\text { tani dalam mengembangkan } \\
\text { kelompok tani, membangun } \\
\text { komitmen anggota, dan menjalin } \\
\text { interaksi sosial dengan pihak di luar } \\
\text { kelompok tani (Anantanyu, 2009) }\end{array}$ & $\begin{array}{l}\text { Diukur berdasarkan skor } \\
\text { responden terhadap tingkat } \\
\text { keberlanjutan berbagai kegiatan } \\
\text { dalam kelompok tani dalam } \\
\text { dalam pengembangan usahatani } \\
\text { agroforestry }\end{array}$ & $\begin{array}{l}\text { 1. Sangat rendah } \\
\text { 2. Rendah } \\
\text { 3. Sedang } \\
\text { 4. Tinggi } \\
\text { 5. Sangat tinggi }\end{array}$ \\
\hline $\begin{array}{l}\mathrm{Y}_{3 .} \text { Efektivitas } \\
\text { fungsi dan peran } \\
\text { (Effectiveness of } \\
\text { function and role) }\end{array}$ & $\begin{array}{l}\text { Tingkat kemampuan kelompok tani } \\
\text { dalam mengelola informasi, modal, } \\
\text { dan material yang menyangkut } \\
\text { dengan fungsi perolehan, } \\
\text { pengaturan, } \\
\text { pengerahan dan pemeliharaan, } \\
\text { konflik (Anantanyu, 2009) }\end{array}$ & $\begin{array}{l}\text { Diukur berdasarkan skor } \\
\text { responden terhadap tingkat } \\
\text { efektivitas fungsi dan peran } \\
\text { yang dimiliki kelompok tani } \\
\text { dalam pengembangan usahatani } \\
\text { agroforestry }\end{array}$ & $\begin{array}{l}\text { 1. Sangat rendah } \\
\text { 2. Rendah } \\
\text { 3. Sedang } \\
\text { 4. Tinggi } \\
\text { 5. Sangat tinggi }\end{array}$ \\
\hline $\begin{array}{l}\mathrm{Y}_{4} \text { Pencapaian } \\
\text { tujuan (Achievement } \\
\text { of objectives) }\end{array}$ & $\begin{array}{l}\text { Tingkat pencapaian kelompok } \\
\text { tani terhadap tujuan yang telah } \\
\text { ditetapkan bersama (Anantanyu, } \\
\text { 2009) }\end{array}$ & 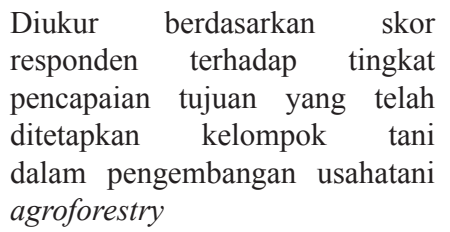 & $\begin{array}{l}\text { 1. Sangat rendah } \\
\text { 2. Rendah } \\
\text { 3. Sedang } \\
\text { 4. Tinggi } \\
\text { 5. Sangat tinggi }\end{array}$ \\
\hline
\end{tabular}

Sumber (Source) : Hasil pengolahan data sekunder (Result of secondary data processing), 2016

Tabel 3. Indikator, definisi, parameter dan kategori pengukuran peran penyuluh

Table 3. Indicators, definition, parameters and measurement category of extension roles

\begin{tabular}{|c|c|c|c|}
\hline Indikator (Indicator) & Definisi (Definition) & $\begin{array}{c}\text { Parameter pengukuran } \\
\text { (Measurement parameter) }\end{array}$ & $\begin{array}{c}\text { Kategori pengukuran } \\
\text { (Measurement } \\
\text { category) } \\
\end{array}$ \\
\hline $\begin{array}{l}\mathrm{X}_{1.1} \text { Peran pendidik } \\
\text { (Educators role) }\end{array}$ & $\begin{array}{l}\text { Kegiatan yang dilakukan oleh } \\
\text { penyuluh dalam membangun } \\
\text { kesadaran, memberikan informasi, } \\
\text { mengajar/melatih petani terkait dengan } \\
\text { pengelolaan usahatani (Suprayitno, } \\
\text { 2011) }\end{array}$ & $\begin{array}{l}\text { Diukur berdasarkan tingkat } \\
\text { intensitas kegiatan penyuluh } \\
\text { dalam mendidik/melatih petani } \\
\text { terkait pengelolaan usahatani }\end{array}$ & $\begin{array}{l}\text { 1. Sangat kecil } \\
\text { 2. Kecil } \\
\text { 3. Sedang } \\
\text { 4. Besar } \\
\text { 5. Sangat besar }\end{array}$ \\
\hline $\begin{array}{l}\mathrm{X}_{1.2} \text { Peran fasilitator } \\
\text { (Facilitator role })\end{array}$ & $\begin{array}{l}\text { Kegiatan yang dilakukan penyuluh } \\
\text { dalam rangka mendorong dan } \\
\text { membantu petani dalam memperlancar } \\
\text { proses pengelolaan usahatani } \\
\text { (Suprayitno, 2011) }\end{array}$ & $\begin{array}{l}\text { Diukur berdasarkan tingkat } \\
\text { intensitas kegiatan penyuluh } \\
\text { dalam memfasilitasi } \\
\text { pengelolaan usahatani }\end{array}$ & $\begin{array}{l}\text { 1. Sangat kecil } \\
\text { 2. Kecil } \\
\text { 3. Sedang } \\
\text { 4. Besar } \\
\text { 5. Sangat besar }\end{array}$ \\
\hline $\begin{array}{l}\mathrm{X}_{1.3} \text { Peran } \\
\text { pendamping } \\
(\text { Companion role })\end{array}$ & $\begin{array}{l}\text { Kegiatan yang dilakukan oleh } \\
\text { penyuluh dalam memberikan nasehat, } \\
\text { pertimbangan, masukan kepada petani } \\
\text { dan pihak lain yang berhubungan } \\
\text { dengan pengelolaan usahatani } \\
\text { (Suprayitno, 2011) }\end{array}$ & $\begin{array}{l}\text { Diukur berdasarkan } \\
\text { tingkat intensitas kegiatan } \\
\text { penyuluh dalam melakukan } \\
\text { pendampingan kepada petani } \\
\text { dalam pengelolaan usahatani }\end{array}$ & $\begin{array}{l}\text { 1. Sangat kecil } \\
\text { 2. Kecil } \\
\text { 3. Sedang } \\
\text { 4. Besar } \\
\text { 5. Sangat besar }\end{array}$ \\
\hline
\end{tabular}

Sumber (Source) : Hasil pengolahan data sekunder (Result of secondary data processing), 2016. 
Tabel 4. Indikator, definisi, parameter dan kategori pengukuran dukungan pihak luar Table 4. Indicators, definition, parameters and measurement category of external supporting

\begin{tabular}{llll}
\hline Indikator (Indicator) & \multicolumn{1}{c}{ Definisi (Definition) } & \multicolumn{1}{c}{$\begin{array}{c}\text { Parameter pengukuran } \\
\text { (Measurement parameter) }\end{array}$} & $\begin{array}{c}\text { Kategori pengukuran } \\
\text { (Measurement } \\
\text { category) }\end{array}$ \\
\hline $\begin{array}{l}\mathrm{X}_{2.1} \text { Dukungan } \\
\text { swasta (Private } \\
\text { supporting) }\end{array}$ & $\begin{array}{l}\text { Tingkat intensitas keterlibatan } \\
\text { pihak swasta membantu kelompok } \\
\text { tani dalam pengembangan }\end{array}$ & $\begin{array}{l}\text { Diukur berdasarkan skor } \\
\text { responden terhadap tingkat } \\
\text { intensitas keterlibatan pihak swasta } \\
\text { dalam pengembangan usahatani }\end{array}$ & $\begin{array}{l}\text { 1. Sangat rendah } \\
\text { 3. Rendah }\end{array}$ \\
& & 4. Tinggi \\
$\mathrm{X}_{2.2}$ Dukungan & Tingkat intensitas keterlibatan & Diukur berdasarkan skor responden & 1. Sangat rendah \\
pemerintah & pemerintah daerah membantu & terhadap tingkat intensitas & 2. Rendah \\
daerah $($ Regional & kelompok tani dalam & keterlibatan pemerintah daerah & 3. Sedang \\
government & pengembangan usahatani & dalam pengembangan usahatani & 4. Tinggi \\
supporting) & agroforestry & agroforestry & 5. Sangat tinggi \\
$\mathrm{X}_{2.3}$ Dukungan & Tingkat intensitas keterlibatan & Diukur berdasarkan skor & 1. Sangat rendah \\
pemerintah pusat & pemerintah pusat membantu & responden terhadap tingkat & 2. Rendah \\
( National & kelompok tani dalam & intensitas keterlibatan pemerintah & 3. Sedang \\
government & pengembangan usahatani & dalam pengembangan usahatani & 4. Tinggi \\
supporting) & agroforestry & agroforestry & 5. Sangat tinggi \\
\hline
\end{tabular}

Sumber (Source) : Hasil pengolahan data sekunder (Result of secondary data processing), 2016.

Tabel 5. Indikator, definisi, parameter dan kategori pengukuran karakteristik anggota Table 5. Indicators, definition, parameters and measurement category of members characteristic

\begin{tabular}{|c|c|c|c|}
\hline Indikator (Indicator) & Definisi (Definition) & $\begin{array}{c}\text { Parameter pengukuran } \\
\text { (Measurement parameter) }\end{array}$ & $\begin{array}{l}\text { Kategori pengukuran } \\
\text { (Measurement category) }\end{array}$ \\
\hline $\begin{array}{l}\mathrm{X}_{3.1} \text { Pendidikan } \\
\text { informal (Informal } \\
\text { education) }\end{array}$ & $\begin{array}{l}\text { Pelatihan yang diperoleh anggota } \\
\text { kelompok tani (di luar pendidikan } \\
\text { formal) yang pernah dan sedang } \\
\text { diikuti oleh anggota (Ruhimat, } \\
\text { 2015) }\end{array}$ & $\begin{array}{l}\text { Diukur berdasarkan jumlah } \\
\text { pelatihan yang diikuti } \\
\text { anggota dalam pengelolaan } \\
\text { usahatani agroforestry }\end{array}$ & $\begin{array}{l}\text { 1. Sangat rendah }(<1 \text { kali) } \\
\text { 2. Rendah }(2-3 \text { kali) } \\
\text { 3. Sedang }(4-5 \text { kali) } \\
\text { 4. Tinggi }(6-7 \text { kali }) \\
\text { 5. Sangat tinggi }(>8 \text { kali) }\end{array}$ \\
\hline $\begin{array}{l}\mathrm{X}_{3.2} \text { Pengalaman } \\
\text { usaha tani (Farmers } \\
\text { experiances })\end{array}$ & $\begin{array}{l}\text { Lamanya waktu yang telah/sedang } \\
\text { dipergunakan oleh anggota dalam } \\
\text { melakukan kegiatan usahatani } \\
\text { (Ruhimat, 2015) }\end{array}$ & $\begin{array}{l}\text { Diukur berdasarkan } \\
\text { lamanya waktu (tahun) } \\
\text { yang telah/ sedang } \\
\text { dipergunakan oleh anggota } \\
\text { dalam melakukan kegiatan } \\
\text { usaha tani }\end{array}$ & $\begin{array}{l}\text { 1. Sangat rendah }(<5 \text { tahun }) \\
\text { 2. Rendah }(5-10 \text { tahun }) \\
\text { 3. Sedang }(11-15 \text { tahun }) \\
\text { 4. Tinggi (16-20 tahun) } \\
\text { 5. Sangat tinggi ( }>20 \text { tahun })\end{array}$ \\
\hline $\begin{array}{l}\mathrm{X}_{3.3} \text { Tingkat } \\
\text { kosmopolitan } \\
\text { (Cosmopolitan level) }\end{array}$ & $\begin{array}{l}\text { Tingkat intensitas anggota (petani) } \\
\text { dalam melakukan hubungan atau } \\
\text { kontak dengan berbagai sumber } \\
\text { informasi, baik yang berada di } \\
\text { dalam maupun di luar petani } \\
\text { (Suprayitno, 2011) }\end{array}$ & $\begin{array}{l}\text { Diukur berdasarkan skor } \\
\text { responden terhadap tingkat } \\
\text { intensitas hubungan antara } \\
\text { anggota dengan berbagai } \\
\text { sumber informasi tentang } \\
\text { usahatani agroforestry }\end{array}$ & $\begin{array}{l}\text { Sangat rendah } \\
\text { Rendah } \\
\text { Sedang } \\
\text { Tinggi } \\
\text { Sangat tinggi }\end{array}$ \\
\hline
\end{tabular}

Sumber (Source) : Hasil pengolahan data sekunder (Result of secondary data processing), 2016. 
Tabel 6 Indikator, definisi, parameter dan kategori pengukuran kapasitas anggota

Table 6. Indicators, definition, parameters and measurement category of members'capacity

\begin{tabular}{|c|c|c|c|}
\hline Indikator (Indicator) & Definisi (Definition) & $\begin{array}{l}\text { Parameter pengukuran } \\
\text { (Measurement parameter) }\end{array}$ & $\begin{array}{c}\text { Kategori pengukuran } \\
\text { (Measurement } \\
\text { category) }\end{array}$ \\
\hline $\begin{array}{l}\mathrm{X}_{4.1} \text { Kapasitas } \\
\text { teknis (Technical } \\
\text { capacity) }\end{array}$ & $\begin{array}{l}\text { Seperangkat kemampuan yang } \\
\text { berkaitan dengan pengetahuan, } \\
\text { keterampilan tentang sistem } \\
\text { usaha tani, mulai dari pembibitan, } \\
\text { pengolahan lahan, pemeliharaan } \\
\text { tanaman, pemanenan dan pemasaran } \\
\text { hasil (Suprayitno, } 2011\end{array}$ & $\begin{array}{l}\text { Diukur berdasarkan skor } \\
\text { responden terhadap kemampuan } \\
\text { anggota (petani) yang } \\
\text { berhubungan dengan unsur-unsur } \\
\text { teknis dalam pengembangan } \\
\text { usahatani agroforestry }\end{array}$ & $\begin{array}{l}\text { 1.Sangat rendah } \\
\text { 2. Rendah } \\
\text { 3. Sedang } \\
\text { 4. Tinggi } \\
\text { 5. Sangat tinggi }\end{array}$ \\
\hline $\begin{array}{l}\mathrm{X}_{4.2} \text { Kapasitas } \\
\text { manajerial } \\
\text { (Managerial } \\
\text { capacity) }\end{array}$ & $\begin{array}{l}\text { Seperangkat kemampuan yang } \\
\text { dimiliki anggota (petani) berupa } \\
\text { pengetahuan, keterampilan dan } \\
\text { sikap yang berhubungan dengan } \\
\text { unsur-unsur manajerial seperti } \\
\text { merencanakan, mengorganisasikan, } \\
\text { melaksanakan, mengawasi dan } \\
\text { mengevaluasi kegiatan usaha tani } \\
\text { yang dilakukannya secara baik dan } \\
\text { benar (Suprayitno, 2011) }\end{array}$ & $\begin{array}{l}\text { Diukur berdasarkan skor } \\
\text { responden terhadap kemampuan } \\
\text { anggota (petani) yang } \\
\text { berhubungan dengan unsur-unsur } \\
\text { manajerial dalam pengembangan } \\
\text { usahatani_agroforestry }\end{array}$ & $\begin{array}{l}\text { 1. Sangat rendah } \\
\text { 2. Rendah } \\
\text { 3. Sedang } \\
\text { 4. Tinggi } \\
\text { 5. Sangat tinggi }\end{array}$ \\
\hline $\begin{array}{l}\mathrm{X}_{4.3} \text { Kapasitas sosial } \\
\text { (Social capacity) }\end{array}$ & $\begin{array}{l}\text { Kemampuan petani untuk } \\
\text { membangun hubungan interpersonal } \\
\text { dalam kelompok, kemampuan } \\
\text { bernegosiasi dan mengembangkan } \\
\text { jejaring atau kemitraan dengan pihak } \\
\text { lain, yang pada prinsipnya didasarkan } \\
\text { pada kemampuan komunikasi } \\
\text { anggota (petani) (Suprayitno, 2011). }\end{array}$ & $\begin{array}{l}\text { Diukur berdasarkan } \\
\text { skor responden terhadap } \\
\text { kemampuan anggota (petani) } \\
\text { yang berhubungan dengan } \\
\text { membangun hubungan } \\
\text { interpersonal dalam kelompok, } \\
\text { kemampuan bernegosiasi dan } \\
\text { mengembangkan jejaring atau } \\
\text { kemitraan dengan pihak lain }\end{array}$ & $\begin{array}{l}\text { 1. Sangat rendah } \\
\text { 2. Rendah } \\
\text { 3. Sedang } \\
\text { 4. Tinggi } \\
\text { 5. Sangat tinggi }\end{array}$ \\
\hline
\end{tabular}

Sumber (Source) : Hasil pengolahan data sekunder (Result of secondary data processing), 2016.

Tabel 7. Indikator, definisi, parameter dan kategori pengukuran peran ketua kelompok tani

Table 7. Indicators, definition, parameters and measurement category of the role of farmer groups leader

\begin{tabular}{|c|c|c|c|}
\hline $\begin{array}{l}\text { Indikator } \\
\text { (Indicator) }\end{array}$ & Definisi (Definition) & $\begin{array}{l}\text { Parameter pengukuran } \\
\text { (Measurement parameter) }\end{array}$ & $\begin{array}{l}\text { Kategori pengukuran } \\
\text { (Measurement category) }\end{array}$ \\
\hline $\begin{array}{l}\mathrm{X}_{5.1} \text { Koordinator } \\
\text { (Coordinator) }\end{array}$ & $\begin{array}{l}\text { Peran ketua kelompok tani dalam } \\
\text { menjelaskan dan mengoordinir } \\
\text { anggota kelompok tani dalam } \\
\text { pengembangan usahatani (Hermanto } \\
\text { \& Swastika, 2011) }\end{array}$ & $\begin{array}{l}\text { Diukur berdasarkan skor } \\
\text { responden tentang seberapa besar } \\
\text { peran ketua kelompok tani dalam } \\
\text { mengkoordinir anggota dalam } \\
\text { kegiatan pengembangan usahatani } \\
\text { agroforestry }\end{array}$ & $\begin{array}{l}\text { 1. Sangat kecil } \\
\text { 2. Kecil } \\
\text { 3. Sedang } \\
\text { 4. Besar } \\
\text { 5. Sangat besar }\end{array}$ \\
\hline $\begin{array}{l}\mathrm{X}_{5.2} \text { Inspirator } \\
\text { (Inspirator) }\end{array}$ & $\begin{array}{l}\text { Segala kegiatan yang dilakukan } \\
\text { ketua kelompok tani yang } \\
\text { dapat menginspirasi anggota } \\
\text { dalam pengembangan usahatani } \\
\text { agroforestry }\end{array}$ & $\begin{array}{l}\text { Diukur berdasarkan skor } \\
\text { responden tentang seberapa } \\
\text { besar peran ketua kelompok tani } \\
\text { dalam menginspirasi anggota } \\
\text { untuk mengembangkan usahatani } \\
\text { agroforestry }\end{array}$ & $\begin{array}{l}\text { 1. Sangat kecil } \\
\text { 2. Kecil } \\
\text { 3. Sedang } \\
\text { 4. Besar } \\
\text { 5. Sangat besar }\end{array}$ \\
\hline $\begin{array}{l}\mathrm{X}_{5.3} \text { Motivator } \\
\text { (Motivator) }\end{array}$ & $\begin{array}{l}\text { Peran ketua kelompok tani untuk } \\
\text { memberikan dan membangkitkan } \\
\text { motivasi anggota kelompok untuk } \\
\text { turut serta dalam pengembangan } \\
\text { usahatani agroforestry }\end{array}$ & $\begin{array}{l}\text { Diukur berdasarkan skor } \\
\text { responden tentang seberapa } \\
\text { besar peran ketua kelompok } \\
\text { tani dalam memotivasi anggota } \\
\text { untuk mengembangan usahatani } \\
\text { agroforestry }\end{array}$ & $\begin{array}{l}\text { 1. Sangat kecil } \\
\text { 2. Kecil } \\
\text { 3. Sedang } \\
\text { 4. Besar } \\
\text { 5. Sangat besar }\end{array}$ \\
\hline
\end{tabular}

Sumber (Source) : Hasil pengolahan data sekunder (Result of secondary data processing), 2016. 
Tabel 8. Indikator, definisi, parameter dan kategori pengukuran kedinamisan kelompok tani Table 8. Indicators, definition, parameters and measurement category of farmer groups dinamysm

\begin{tabular}{|c|c|c|c|}
\hline $\begin{array}{l}\text { Indikator } \\
\text { (Indicator) }\end{array}$ & Definisi (Definition) & $\begin{array}{l}\text { Parameter pengukuran } \\
\text { (Measurement parameter) }\end{array}$ & $\begin{array}{l}\text { Kategori pengukuran } \\
\text { (Measurement category) }\end{array}$ \\
\hline $\begin{array}{l}\mathrm{X}_{6.1} \text { Tingkat } \\
\text { kekompakan } \\
\text { (Cohesion level) }\end{array}$ & $\begin{array}{l}\text { Tingkat keterikatan antara } \\
\text { anggota dengan kelompok tani } \\
\text { (Lestari, 2012) }\end{array}$ & $\begin{array}{l}\text { Diukur berdasarkan skor yang } \\
\text { diberikan responden terhadap } \\
\text { tingkat keterikatan responden } \\
\text { terhadap kelompok tani }\end{array}$ & $\begin{array}{l}\text { 1. Sangat rendah } \\
\text { 2. Rendah } \\
\text { 3. Sedang } \\
\text { 4. Tinggi } \\
\text { 5. Sangat tinggi }\end{array}$ \\
\hline $\begin{array}{l}\mathrm{X}_{6.2} \text { Kejelasan } \\
\text { fungsi dan peran } \\
\text { (Clarity of } \\
\text { function and role) }\end{array}$ & $\begin{array}{l}\text { Tingkat kejelasan kegiatan- } \\
\text { kegiatan yang harus dilakukan } \\
\text { kelompok dalam mencapai tujuan } \\
\text { kelompok (Lestari, 2012) }\end{array}$ & $\begin{array}{l}\text { Diukur berdasarkan skor yang } \\
\text { diberikan responden terhadap } \\
\text { kejelasan fungsi dan peran } \\
\text { kelompok tani dalam mencapai } \\
\text { tujuan kelompok }\end{array}$ & $\begin{array}{l}\text { 1. Sangat rendah } \\
\text { 2. Rendah } \\
\text { 3. Sedang } \\
\text { 4. Tinggi } \\
\text { 5. Sangat tinggi }\end{array}$ \\
\hline $\begin{array}{l}\mathrm{X}_{6.3} \text { Kejelasan } \\
\text { struktur (Clarity } \\
\text { of structure) }\end{array}$ & $\begin{array}{l}\text { Tingkat kejelasan hubungan } \\
\text { antara individu-individu di dalam } \\
\text { kelompok yang disesuaikan } \\
\text { dengan fungsi dan peran masing- } \\
\text { masing individu (Lestari, 2012) }\end{array}$ & $\begin{array}{l}\text { Diukur berdasarkan skor yang } \\
\text { diberikan responden terhadap } \\
\text { tingkat kejelasan hubungan antar } \\
\text { individu dalam kelompok }\end{array}$ & $\begin{array}{l}\text { 1. Sangat rendah } \\
\text { 2. Rendah } \\
\text { 3. Sedang } \\
\text { 4. Tinggi } \\
\text { 5. Sangat tinggi }\end{array}$ \\
\hline $\begin{array}{l}\mathrm{X}_{6.4} \text { Kejelasan } \\
\text { tujuan (Clarity of } \\
\text { purpose) }\end{array}$ & $\begin{array}{l}\text { Tingkat kejelasan hasil yang } \\
\text { diharapkan untuk dicapai oleh } \\
\text { kelompok tani (Lestari, 2012) }\end{array}$ & $\begin{array}{l}\text { Diukur berdasarkan skor yang } \\
\text { diberikan responden terhadap } \\
\text { tingkat kejelasan hasil yang ingin } \\
\text { dicapai oleh kelompok tani }\end{array}$ & $\begin{array}{l}\text { 1. Sangat rendah } \\
\text { 2. Rendah } \\
\text { 3. Sedang } \\
\text { 4. Tinggi } \\
\text { 5. Sangat tinggi }\end{array}$ \\
\hline $\begin{array}{l}\mathrm{X}_{6.5} \text { Suasana } \\
\text { kelompok } \\
\text { (Group } \\
\text { atmosphere) }\end{array}$ & $\begin{array}{l}\text { Suasana yang menentukan reaksi } \\
\text { anggota terhadap anggota lain } \\
\text { atau kelompoknya seperti rasa } \\
\text { hangat, setia kawan, rasa takut } \\
\text { dan saling mencurigai, sikap } \\
\text { saling menerima dan sebagainya } \\
\text { (Lestari, 2012) }\end{array}$ & $\begin{array}{l}\text { Diukur berdasarkan skor yang } \\
\text { diberikan responden terhadap } \\
\text { suasana kelompok tani dalam } \\
\text { mencapai tujuan kelompok tani }\end{array}$ & $\begin{array}{l}\text { 1. Sangat tidak kondusif } \\
\text { 2. Tidak kondusif } \\
\text { 3. Biasa } \\
\text { 4. Kondusif } \\
\text { 5. Sangat kondusif }\end{array}$ \\
\hline
\end{tabular}

Sumber (Source) : Hasil pengolahan data sekunder (Result of secondary data processing), 2016.

Tabel 9. Indikator, definisi, parameter dan kategori pengukuran partisipasi anggota Table 9. Indicators, definition, parameters and measurement category of members 'participation

\begin{tabular}{|c|c|c|c|}
\hline $\begin{array}{l}\text { Indikator } \\
\text { (Indicator) }\end{array}$ & Definisi (Definition) & $\begin{array}{c}\text { Parameter pengukuran } \\
\text { (Measurement parameter) }\end{array}$ & $\begin{array}{c}\text { Kategori pengukuran } \\
\text { (Measurement } \\
\text { category) }\end{array}$ \\
\hline $\begin{array}{l}\mathrm{X} \cdot{ }_{7.1} \text { Partisipasi } \\
\text { dalam } \\
\text { perencanaan } \\
\text { (Participation in } \\
\text { plannning) }\end{array}$ & $\begin{array}{l}\text { Tingkat keikutsertaan anggota } \\
\text { dalam proses perencanaan } \\
\text { kegiatan-kegiatan kelompok } \\
\text { tani yang berhubungan dengan } \\
\text { pengembangan usahatani } \\
\text { agroforestry }\end{array}$ & $\begin{array}{l}\text { Diukur berdasarkan skor yang } \\
\text { diberikan responden terhadap tingkat } \\
\text { keikutsertaan anggota dalam proses } \\
\text { perencanaan kegiatan kelompok } \\
\text { tani dalam pengembangan usahatani } \\
\text { agroforestry }\end{array}$ & $\begin{array}{l}\text { 1. Sangat rendah } \\
\text { 2. Rendah } \\
\text { 3. Sedang } \\
\text { 4. Tinggi } \\
\text { 5. Sangat tinggi }\end{array}$ \\
\hline $\begin{array}{l}\mathrm{X}_{7.2} \text { Partisipasi } \\
\text { dalam } \\
\text { pelaksanaan } \\
\text { (Participation in } \\
\text { implementation) }\end{array}$ & $\begin{array}{l}\text { Tingkat keikutsertaan anggota } \\
\text { dalam pelaksanaan kegiatan- } \\
\text { kegiatan kelompok tani } \\
\text { yang berhubungan dengan } \\
\text { pengembangan usahatani } \\
\text { agroforestry }\end{array}$ & $\begin{array}{l}\text { Diukur berdasarkan skor yang } \\
\text { diberikan responden terhadap } \\
\text { tingkat keikutsertaan anggota dalam } \\
\text { pelaksanaan kegiatan kelompok } \\
\text { tani dalam pengembangan usahatani } \\
\text { agroforestry }\end{array}$ & $\begin{array}{l}\text { 1. Sangat rendah } \\
\text { 2. Rendah } \\
\text { 3. Sedang } \\
\text { 4. Tinggi } \\
\text { 5. Sangat tinggi }\end{array}$ \\
\hline
\end{tabular}




\begin{tabular}{|c|c|c|c|}
\hline $\begin{array}{l}\text { Indikator } \\
\text { (Indicator) }\end{array}$ & Definisi (Definition) & $\begin{array}{l}\text { Parameter pengukuran } \\
\text { (Measurement parameter) }\end{array}$ & $\begin{array}{l}\text { Kategori pengukuran } \\
\text { (Measurement } \\
\text { category) }\end{array}$ \\
\hline $\begin{array}{l}\mathrm{X}_{7.3} \text { Partisipasi } \\
\text { dalam } \\
\text { pemeliharaan } \\
\text { hasil } \\
\text { (Participation in } \\
\text { the mantenence } \\
\text { of the result) }\end{array}$ & $\begin{array}{l}\text { Tingkat keikutsertaan anggota } \\
\text { dalam pemeliharaan hasil } \\
\text { kegiatan-kegiatan kelompok } \\
\text { tani yang berhubungan dengan } \\
\text { pengembangan usahatani } \\
\text { agroforestry }\end{array}$ & $\begin{array}{l}\text { Diukur berdasarkan skor yang } \\
\text { diberikan responden terhadap } \\
\text { tingkat keikutsertaan anggota dalam } \\
\text { pemeliharaan hasil kegiatan kelompok } \\
\text { tani dalam pengembangan usahatani } \\
\text { agroforestry }\end{array}$ & $\begin{array}{l}\text { 1. Sangat rendah } \\
\text { 2. Rendah } \\
\text { 3. Sedang } \\
\text { 4. Tinggi } \\
\text { 5. Sangat tinggi }\end{array}$ \\
\hline $\begin{array}{l}\mathrm{X}_{7.4} \text { Partisipasi } \\
\text { dalam } \\
\text { pemanfaatan } \\
\text { hasil } \\
\text { (Participation in } \\
\text { the utilization of } \\
\text { result) }\end{array}$ & $\begin{array}{l}\text { Tingkat keikutsertaan anggota } \\
\text { dalam pemanfaatan hasil dari } \\
\text { kegiatan-kegiatan kelompok } \\
\text { tani yang berhubungan dengan } \\
\text { pengembangan usahatani } \\
\text { agroforestry }\end{array}$ & $\begin{array}{l}\text { Diukur berdasarkan skor yang } \\
\text { diberikan responden terhadap } \\
\text { tingkat keikutsertaan anggota dalam } \\
\text { pemanfaatan hasil dari kegiatan } \\
\text { kelompok tani dalam pengembangan } \\
\text { usahatani agroforestry }\end{array}$ & $\begin{array}{l}\text { 1. Sangat rendah } \\
\text { 2. Rendah } \\
\text { 3. Sedang } \\
\text { 4. Tinggi } \\
\text { 5. Sangat tinggi }\end{array}$ \\
\hline $\begin{array}{l}\mathrm{X}_{7.5} \text { Partisipasi } \\
\text { dalam } \\
\text { monitoring } \\
\text { evaluasi } \\
\text { (Participation in } \\
\text { monitoring and } \\
\text { evaluation) }\end{array}$ & $\begin{array}{l}\text { Tingkat keikutsertaan anggota } \\
\text { dalam monitoring evaluas pada } \\
\text { kegiatan-kegiatan kelompok } \\
\text { tani yang berhubungan dengan } \\
\text { pengembangan usahatani } \\
\text { agroforestry }\end{array}$ & $\begin{array}{l}\text { Diukur berdasarkan skor yang } \\
\text { diberikan responden terhadap tingkat } \\
\text { keikutsertaan anggota dalam monitoring } \\
\text { evaluasi dalam kegiatan kelompok } \\
\text { tani dalam pengembangan usahatani } \\
\text { agroforestry }\end{array}$ & $\begin{array}{l}\text { 1. Sangat rendah } \\
\text { 2. Rendah } \\
\text { 3. Sedang } \\
\text { 4. Tinggi } \\
\text { 5. Sangat tinggi }\end{array}$ \\
\hline
\end{tabular}

Sumber (Source) : Hasil pengolahan data sekunder (Result of secondary data processing), 2016.

kelembagaan kelompok tani seperti pada Gambar 3.

Gambar 3 memperlihatkan faktorfaktor yang berpengaruh terhadap kapasitas kelembagaan kelompok tani terdiri dari faktor yang berpengaruh langsung dan tidak langsung.

Faktor yang berpengaruh langsung terhadap kapasitas kelembagaan kelompok tani

Hasil analisis SEM seperti disajikan dalam Gambar 3 memperlihatkan bahwa tingkat kedinamisan kelompok tani dan partisipasi anggota pada setiap kegiatan kelompok tani memiliki pengaruh langsung terhadap tingkat kapasitas kelembagaan kelompok tani dalam pengembangan usahatani agroforestry. Adapun persamaan struktural pengaruh kedua faktor terhadap kapasitas kelembagaan kelompok tani adalah sebagai berikut:

$$
\begin{aligned}
& Y=0,568 \times 6+0,400 \times 7+\zeta \\
& R 2=0,9340 \text { atau } 93,40 \%
\end{aligned}
$$

Keterangan (Remarks):

$\mathrm{Y}=$ kapasitas kelembagaan kelompok tani; $\mathrm{X} 6=$ tingkat kedinamisan kelompok tani; $\mathrm{X} 7=$ partisipasi anggota; $\zeta=$ faktor yang berpengaruh terhadap kapasitas kelembagaan kelompok tani selain tingkat kedinamisan dan partisipasi anggota kelompok tani; R2 = besaran pengaruh tingkat kedinamisan dan partisipasi anggota kelompok tani secara bersama-sama terhadap kapasitas kelembagaan kelompok tani

Berdasarkan persamaan struktural yang dihasilkan maka besaran total pengaruh kedinamisan dan partisipasi anggota kelompok taniterhadapkapasitas kelembagaankelompok tani adalah sebesar 0,9340 atau 93,40\%. Angka sebesar 93,40\%. menunjukkan bahwa kedua faktor tersebut berpengaruh sangat kuat terhadap tingkat kapasitas kelembagaan kelompok tani sedangkan pengaruh di luar kedua faktor hanya sebesar $6,6 \%$.

Kedinamisan kelompok tani merupakan faktor yang memiliki pengaruh paling besar terhadapkapasitas kelembagaankelompoktani sehingga rendahnya kedinamisan kelompok tani akan menyebabkan rendahnya kapasitas kelembagaan kelompok tani. Wawancara 


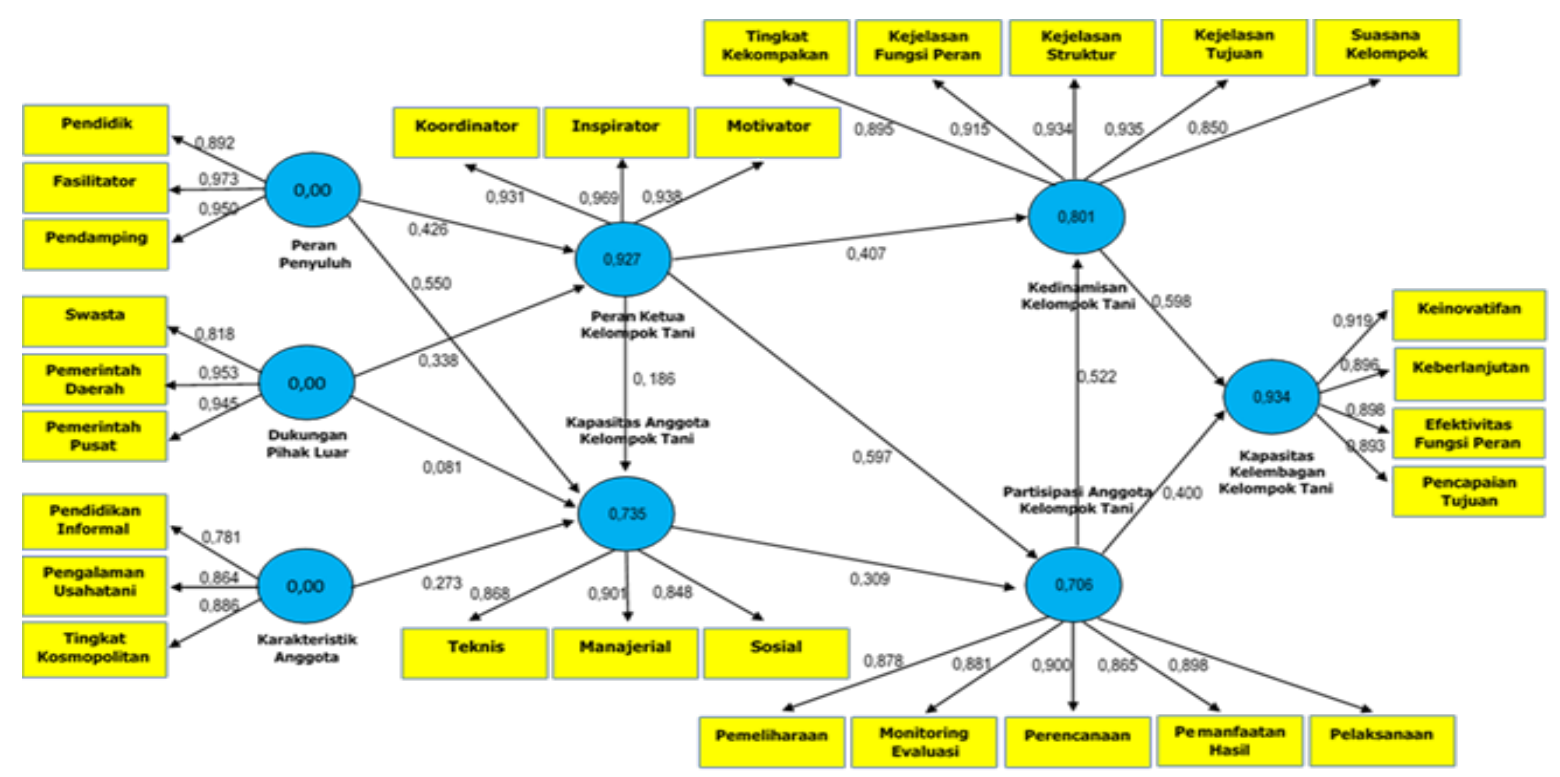

Sumber (Source) : Hasil analisis data primer (Result of primary data analysis), 2016

Gambar 3. Model struktural faktor-faktor yang berpengaruh terhadap kapasitas kelembagaan kelompok tani Figure 3. Structural model of the factors that influence the institutional capacity of farmer groups

secara mendalam dengan pengurus kelompok tani dan penyuluh menunjukkan bahwa kelompok tani di Desa Cukangkawung telah memiliki tujuan dan struktur organisasi, tetapi masih belum sesuai dengan harapan. Kelompok tani belum dapat berperan sebagai wahana belajar, kerja sama, dan unit produksi bersama untuk para anggota. Struktur kelompok tani hanya menjadi prasyarat administrasi sebuah organisasi, sehingga berdampak pada rendahnya peran dan fungsi pengurus kelompok tani. Rendahnya efektivitas peran, fungsi, dan struktur kelompok tani menyebabkan rendahnya tingkat kedinamisan.

Penyuluh yang bertugas di Desa Cukangkawung mengemukakan rendahnya kedinamisan kelompok tani disebabkan kekompakan yang belum terbentuk. Lestari (2012) menyebutkan rendahnya tingkat kekompakan dan belum terbentuknya suasana yang dinamis disebabkan oleh belum terjalinnya kerja sama dan komunikasi antara pengurus dengan anggota atau di antara anggota.
Partisipasi seluruh anggota kelompok tani merupakan faktor kedua yang memiliki pengaruh langsung terhadap kapasitas kelembagaan kelompok tani. Secara umum, partisipasi anggota dalam setiap kegiatan kelompok tani masih rendah, terutama partisipasi dalam perencanaan, pengawasan, dan pemeliharaan hasil kegiatan kelompok tani. Berdasarkan hasil diskusi dengan pengurus kelompok tani dan penyuluh diperoleh informasi bahwa tingkat partisipasi anggota kelompok tani masih rendah. Namun demikian, partisipasi dalam pemanfaatan hasil kegiatan, mengalami peningkatan ketika ada program bantuan pemerintah dalam bentuk sarana dan prasarana usahatani.

Faktor yang berpengaruh tidak langsung terhadap kapasitas kelembagaan kelompok tani

Hasil analisis SEM seperti Gambar 3 menggambarkan bahwa faktor yang berpengaruh tidak langsung terhadap kapasitas kelembagaan kelompok tani terdiri dari (i) peran ketua, (ii) kapasitas anggota, (iii) peran penyuluh, (iv) dukungan pihak luar, 
dan (v) karakteristik anggota. Berdasarkan hasil analisis SEM tingkat efektivitas peran ketua kelompok tani (koordinator, motivator, dan inspirator) merupakan faktor pertama yang berpengaruh tidak langsung terhadap kapasitas kelembagaan kelompok tani.

Efektivitas peran ketua kelompok akan berpengaruh terhadap tingkat kapasitas anggota kelompok tani, tingkat kedinamisan kelompok tani, dan tingkat partisipasi anggota kelompok tani sehingga secara tidak langsung akan berpengaruh terhadap kapasitas kelembagaan kelompok tani. FGD dengan stakeholder terkait menyimpulkan peran ketua kelompok tani memiliki peranan penting dalam mengkoordinasi, memotivasi dan menginspirasi anggota kelompok tani untuk berpartisipasi secara aktif dalam setiap kegiatan kegiatan kelompok tani. Hal ini sejalan dengan hasil penelitian yang dilakukan oleh Saptorini (2013) di Kabupaten Kebumen, Jawa Tengah; Mutmainah and Sumardjo (2014) di Desa Situ Udik, Kecamatan Cibungbulang, Kabupaten Bogor serta Hermanto dan Swastika (2011) di Provinsi Bangka Belitung dan Sumatera Selatan.

Kapasitas anggota merupakan faktor kedua yang berpengaruh tidak langsung terhadap kapasitas kelembagaan kelompok tani. Hal ini mengandung pengertian bahwa peningkatan kapasitas anggota (manajerial, teknis, dan sosial) akan berpengaruh terhadap kapasitas kelembagaan kelompok tani melalui peningkatan partisipasi anggota kelompok tani. Anantanyu (2009) mengemukakan kapasitas petani merupakan salah satu faktor yang menggerakan petani untuk berpartisipasi aktif dalam kegiatan pertanian seperti kelompok tani.

Peran penyuluh menjadi faktor ketiga yang berpengaruh tidak langsung terhadap kapasitas kelembagaan kelompok tani. Hasil analisis SEM seperti pada Gambar 3 menggambarkan penyuluh memiliki peran penting dalam meningkatkan efektivitas peran pemimpin dan kapasitas anggota kelompok tani. Stakeholder dalam pengembangan usahatani agroforestry (pemerintah, swasta, dan petani) berpendapat optimalisasi peran penyuluh (pendidik, pendamping, dan fasilitator) sangat diperlukan untuk keberhasilan pengembangan usahatani agroforestry di Desa Cukangkawung. Anantanyu (2009) mengemukakan peran penyuluh sangat diperlukan untuk meningkatkan kepercayaan, motivasi, dan kapasitas pengurus serta anggota kelompok tani dalam berbagai kegiatan pertanian.

Dukungan pihak luar yang terdiri dari dukungan pihak swasta, pemerintah pusat, dan pemerintah daerah merupakan faktor keempat yang berpengaruh tidak langsung terhadap kapasitas kelembagaan kelompok tani. Penyuluh mengemukakan dukungan pihak luar terhadap peningkatan kapasitas kelembagaan kelompok tani sangat diperlukan dalam proses peningkatkan kapasitas pengurus dan anggota kelompok tani. Sumiati (2011) dan Anantanyu (2009) mengemukakan dukungan berbagai pihak sangat diperlukan dalam proses penguatan kapasitas kelembagaan kelompok tani seperti dukungan kebijakan, kemitraan, biaya, ilmu pengetahuan dan teknologi, dan tenaga pendamping.

Karakteristik anggota kelompok tani merupakan faktor kelima yang berpengaruh tidak langsung terhadap kapasitas kelembagaan kelompok tani. Karakteristik anggota dalam penelitian ini terdiri dari tingkat kosmopolitan anggota, pendidikan informal, dan pengalaman usahatani. Berdasarkan hasil analisis SEM tingkat kosmopolitan petani merupakan aspek dalam faktor karakteristik petani yang memiliki pengaruh paling besar terhadap proses peningkatan kapasitas anggota (kapasitas sosial, manajerial, dan teknis). Tingkat kosmopolitan petani masih rendah, hal ini dapat dilihat dari rendahnya kemampuan petani untuk berusaha mengakses informasi pertanian agroforestry dari berbagai sumber informasi sehingga mengakibatkan masih rendahnya kapasitas petani. Suprayitno, Sumardjo, Gani, dan Sugihen (2012) menyebutkan tingkat kosmopolitan petani 


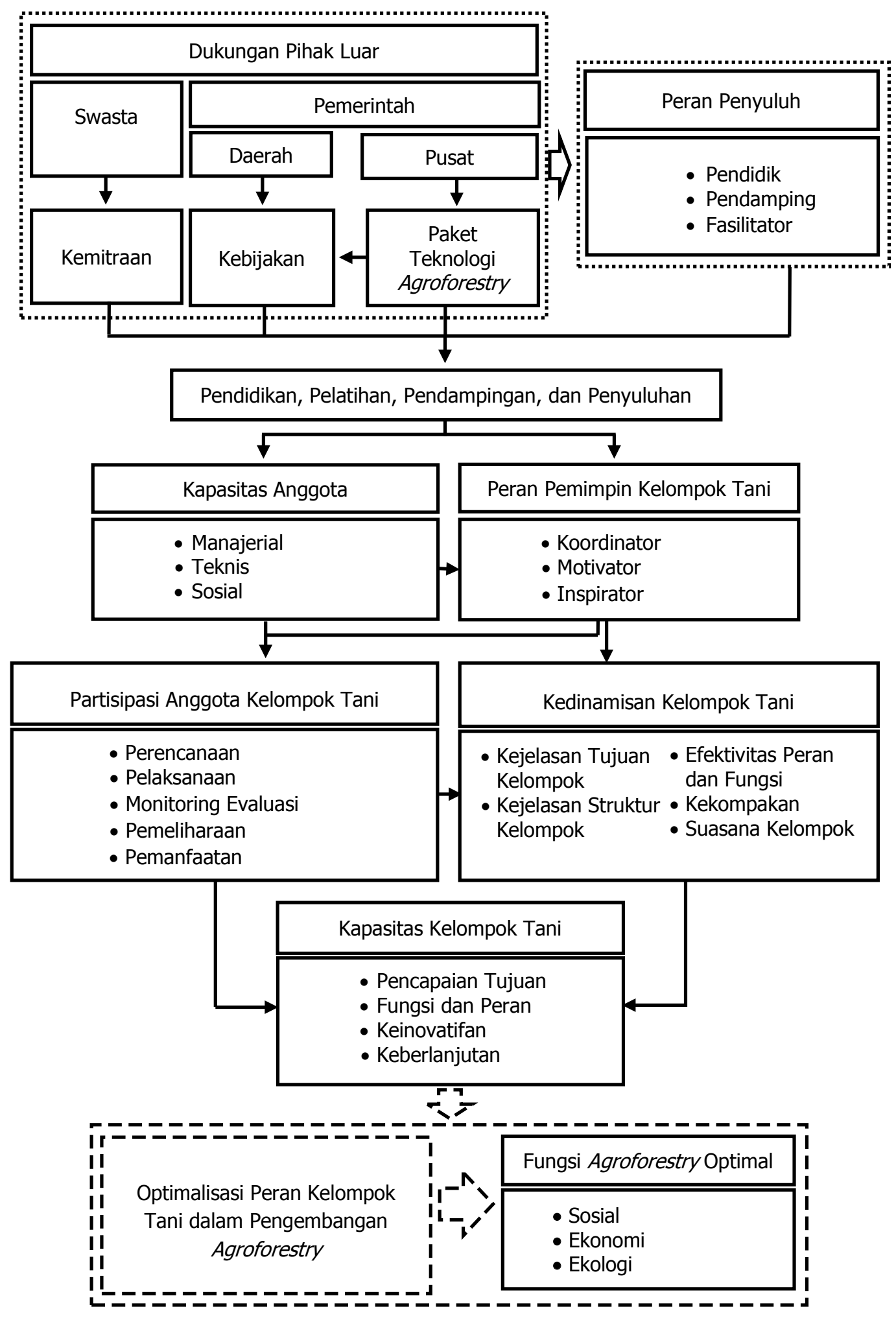

Sumber (Source) : Hasil analisis data primer (Result of primary data analysis), 2016

Gambar 4. Usaha peningkatan kapasitas kelembagaan kelompok tani di Desa Cukangkawung Figure 4. Efforts to institutional capacity building of farmer groups in Cukangkawung Village 
direfleksikan oleh aksesibilitas petani terhadap sumber informasi, semakin luas akses petani terhadap sumber informasi maka semakin luas wawasan dan pengetahun petani. Luasnya wawasan dan pengetahuan petani akan berpengaruh positif terhadap peningkatan kapasitas petani dalam pengelolaan usahatani.

\section{B. Usaha peningkatan kapasitas kelembagaan kelompok tani}

Hasil analisis SEM seperti pada Gambar 3 menunjukkan peningkatan kapasitas kelembagaan dapat dilakukan dengan meningkatkan kedinamisan kelompok tani dan partisipasi seluruh anggota. Usaha ini dapat dilakukan dengan menganalisis faktorfaktor yang berpengaruh terhadap kedua faktor tersebut seperti disajikan pada Gambar 4. Peningkatan kedinamisan kelompok tani dapat dilakukan dengan cara meningkatkan partisipasi anggota kelompok tani dalam setiap tahapan kegiatan seperti perencanaan, pelaksanaan, pengawasan evaluasi, pemeliharaan dan pemanfaatan hasil. Selain itu, peningkatan kedinamisan kelompok tani dapat dilakukan dengan mengoptimalkan peran ketua kelompok dalam mengkoordinir, memotivasi, dan menginspirasi anggota kelompok tani.

Peningkatan partisipasi anggota kelompok tani dapat dilakukan dengan cara mengoptimalkan peran ketua kelompok tani dan meningkatkan kapasitas (kapasitas manajerial, teknis, dan sosial) yang dimiliki oleh anggota.

Gambar4menunjukkan bahwa pelaksanaan pendidikan, pelatihan, penyuluhan dan pembinaan (diklatluhbin) terhadap seluruh anggota dan ketua kelompok tani merupakan salah satu cara untuk meningkatkan kapasitas anggota dan peran ketua kelompok tani. Peningkatan peran dan kapasitas petani (ketua dan anggota kelompok tani) memerlukan dukungan yang kuat dari berbagai pihak (Sumarlan, Sumardjo, Prabowo, \& Darwis, 2012).

Pengembangan usahatani agroforestry yang didukung oleh peran optimal dari masingmasing stakeholder akan berpengaruh positif terhadap efektivitas pelaksanaan pendidikan, pelatihan, penyuluhan dan pembinaan kelompok tani. Hal tersebut akan berdampak kepada peningkatan kapasitas anggota dan peran ketua kelompok tani.

Tingginya kapasitas anggota dan peran ketua kelompok tani akan memotivasi seluruh anggota untuk berpartisipasi aktif dalam setiap kegiatan kelompok, sehingga akan terwujud kelompok tani yang aktif dan dinamis. Tingginya tingkat partisipasi anggota dan kedinamisan kelompok tani akan mampu meningkatkan kapasitas kelembagaan kelompok tani dalam mengoptimalkan peran kelompok sebagai wahana belajar, kerja sama, dan unit produksi bersama untuk seluruh anggota. Anantanyu (2009) menyebutkan kapasitas kelembagaan kelompok tani yang optimal ditandai dengan tingginya tingkat pencapaian tujuan, efektivitas fungsi dan peran struktur, inovatif, dan keberlanjutan kelompok tani.

Peran kelompok tani yang berjalan optimal diharapkan dapat mendukung keberhasilan pengembangan usahatani agroforestry di Desa Cukangkawung, sehingga fungsi agroforestry dalam meningkatkan nilai tambah ekonomi, sosial, dan lingkungan dapat terwujud.

\section{KESIMPULAN DAN SARAN}

\section{A. Kesimpulan}

Kapasitas kelembagaan kelompok tani merupakan salah satu faktor penting dalam program pengembangan usahatani agroforestry di Desa Cukangkawung. Tingkat kapasitas kelembagaan kelompok tani dipengaruhi secara langsung oleh tingkat kedinamisan kelompok tani dan tingkat partisipasi anggota dalam kegiatan kelompok tani, serta secara tidak langsung dipengaruhi oleh kapasitas anggota, peran ketua, peran penyuluh, dukungan pihak luar, dan karakteristik individu anggota. Usaha yang dapat dilakukan untuk meningkatkan 
kapasitas kelembagaan kelompok tani adalah dengan meningkatkan kedinamisan kelompok tani dan partisipasi anggota dalam setiap kegiatan kelompok tani..

\section{B. Saran}

Pemerintah daerah melalui institusi penyuluhan disarankan untuk mengoptimalkan pelaksanaan pendidikan, pelatihan, penyuluhan, dan pembinaan kelompok tani dalam kegiatan pengembangan usahatani agroforestry. Pemerintah pusat melalui institusi penelitian dan pengembangan (Litbang) disarankan untuk menyediakan paket teknologi agroforestry yang bersifat komprehensif (teknis, sosial, dan ekonomi), dapat diaplikasikan, dan mampu menjawab permasalahan stakeholder di daerah.

Pemerintah daerah (Kabupaten Tasikmalaya dan Provinsi Jawa Barat di sarankan untuk membuat kebijakan pengembangan agroforestry yang dapat mengakomodir hasil penelitian yang dilakukan oleh institusi litbang dan menjamin pelaksanaan program pendidikan, pelatihan, penyuluhan dan pembinaan kelompok tani secara sistematis, terarah, terjadwal, dan berkelanjutan.

\section{UCAPAN TERIMA KASIH (ACKNOWLWDGEMENT)}

Penulis mengucapkan terima kasih kepada seluruh pihak yang telah membantu kelancaran penelitian ini, khususnya kepada para anggota kelompok tani yang terlibat dalam studi ini, Kepala Balai Penelitian Teknologi Agroforestry, Kepala Desa Cukangkawung, Balai Penyuluhan Pertanian Perkebunan dan Kehutanan Kecamatan Sodonghilir, Kepala Dinas Kehutanan dan Perkebunan Kabupaten Tasikmalaya, Dede Rohman, Kurnia, dan Darsono Priono yang telah memberikan fasilitas, dukungan, perhatian, dan bantuan dalam proses pengumpulan data selama penelitian.

\section{DAFTAR PUSTAKA}

Anantanyu. (2009). Partisipasi petani dalam meningkatkan kapasitas kelembagaan kelompok petani. (Disertasi). Bogor: Sekolah Pascasarjana Institut Pertanian Bogor.

BP3K. (2015). Rencana kerja penyuluhan pertanian tahun 2015. Tasikmalaya: Balai Penyuluhan Pertanian Perikanan dan Kehutanan Kecamatan Sodonghilir

BPS. (2014). Kecamatan Sodonghilir dalam angka. Tasikmalaya: Badan Pusat Statistik.

Butarbutar, T. (2012). Agroforestri untuk adaptasi dan mitigasi perubahan iklim. Jurnal Analisis Kebijakan Kehutanan, 9(1), 1-10.

Dachlan, U. (2014). Panduan lengkap structural equation modellling. Semarang: Lentera Ilmu.

Hani, A., Suhaendah, E., Winara, A., Achmad, B., Ruhimat, I. S., Augusta, L., . . Kuswandi, N. (2015). Penerapan model agroforestry kayu pertukangan jenis sengon dan manglid. Ciamis: Balai Penelitian Teknologi Agroforestry.

Harun, M. K. (2011). Analisis pengembangan jelutung dengan sistem agroforestry untuk memulihkan lahan gambut terdegradasi di Provinsi Kalimantan Tengah. (Tesis). Bogor: Sekolah Pascasarjana Institut Pertanian Bogor.

Hermanto, \& Swastika, D. K. S. (2011). Penguatan kelompok tani: langkah awal peningkatan kesejahteraan petani. Jurnal Analisis Kebijakan Pertanian, 9 (4), 371-390.

Hiola, A. S. (2011). Agroforestry Lengi: suatu kajian pelestarian dan pemanfaatan jenis pohon. (Disertasi). Bogor: Sekolah Pascasarjana Institut Pertanian Bogor.

Kuswantoro, D. P., Junaidi, E., Handayani, W., Ruhimat, I. S., Utomo, B., Kuswandi, N., . . . Filianty, D. (2014). Kajian lanskap agroforestry pada DAS prioritas (DAS Cikawung). Ciamis: Balai Penelitian Teknologi Agroforestri.

Lestari, G. I. (2012). Dinamika kelompok tani hutan rakyat di Desa Lemahduhur. (Tesis). Bogor: Sekolah Pascasarjana Institut Pertanian Bogor.

Mayrowani, H., \& Ashari. (2011). Pengembangan agroforestry untuk mendukung ketahanan pangan dan pemberdayaan petani sekitar hutan. Jurnal Forum Penelitian Agro Ekonomi, 29 (2), 83-98.

Mun'im, A. (2012). Analisis faktor ketersediaan, akses dan penyerapan pangan di kabupaten surplus pangan: pendekatan Partial Least Square 
Path Modelling. Jurnal Agroekonomi, 30 (1), 41-56.

Mutmainah, R., \& Sumardjo. (2014). Peranan kepemimpinan kelompok tani dan efektivitas pemberdayaan petani. Jurnal Sodality: Sosiologi Pedesaan, 2 (3), 182-199.

Puspitodjati, T., Junaidi, E., Ruhimat, I. S., Kuswantoro, D. P., Handayani, W., \& Indrajaya, Y. (2013). Kajian lanskap agroforestry pada DAS prioritas (DAS Cimuntur). Ciamis: Balai Penelitian Teknologi Agroforestry..

Rambey, R. (2011). Pengetahuan lokal sistem agroforestry mindi. (Tesis). Bogor: Sekolah Pascasarjana Institut Pertanian Bogor.

Ruhimat, I. S. (2015). Tingkat motivasi petani dalam penerapan sistem agroforestry. Jurnal Sosial Ekonomi Kehutanan, 12 (2), 131-147.

Santoso,S. (2012). Analisis SEM menggunakan AMOS. Jakarta: Elexmedia Komputindo.

Saptorini. (2013). Persepsi anggota kelompok tani terhadap kepemimpinan ketua kelompok tani di Kabupaten Kebumen Jawa Tengah. (Tesis). Bogor: Sekolah Pascasarjana Institut Pertanian Bogor.

Subagio, H. (2008). Peran kapasitas petani dalam mewujudkan keberhasilan usaha tani: kasus petani sayuran dan padi di Kabupaten Malang dan Pasuruan Jawa Timur. (Disertasi). Bogor: Sekolah Pascasarjana Institut Pertanian Bogor,.

Sumarlan, Sumardjo, Prabowo, \& Darwis. (2012). Peningkatan Kinerja Petani Sekitar Hutan dalam Penerapan Sistem Agroforestry di Pegunungan Kendeng Pati. Jurnal Agroekonomi, 30 (1), 25 - 29.
Sumiati. (2011). Analisis kelayakan finansial dan faktor-faktor yang memotivasi petani dalam kegiatan agroforestry: kasus pada proyek pengembangan hutan kemasyarakatan SFDFPPHK di Kabupaten Sanggau, Provinsi Kalimantan Barat. (Tesis). Bogor: Sekolah Pascasarjana, Institut Pertanian Bogor.

Suprayitno, A. (2011). Model peningkatan partisipasi petani sekitar hutan dalam mengelola hutan kemiri rakyat: Kasus pengelolaan hutan kemiri kawasan pegunungan Bulusaraung Kabupaten Maros Sulawesi Selatan. (Disertasi). Bogor: Program Studi Ilmu Penyuluhan Pembangunan, Sekolah Pascasarjana Institut Pertanian Bogor.

Suprayitno, A. R., Sumardjo, Gani, D. S., \& Sugihen, B. G. (2012). Motivasi dan partisipasi petani dalam pengelolaan hutan kemiri di Kabupaten Maros Provinsi Sulawesi Selatan. Jurnal Penyuluhan, 8 (2), 188-199.

Syahyuti. (2011). Gampang-gampang susah mengorganisasikan petani. Bogor: IPB Press.

Umiyati, R. (2015). Diversifikasi hasil kegiatan agroforestry bagi ketahanan pangan di Kecamatan Sigaluh Kabupaten Banjarnegara. Jurnal Ilmiah Teknosains, I (1), 52-56.

Wiyono, G. (2011). Merancang penelitian bisnis dengan SPSS dan SmartPLS 2.0. Yogyakarta: Unit Penerbit dan Percetakan STIM YKPN.

Yunita. (2011). Strategi peningkatan kapasitas petani padi sawah lebak menuju ketahanan pangan rumah tangga di Kabupaten Ogan Ilir dan Ogan Komering Ilir Provinsi Sumatera Selatan. (Disertasi). Bogor: Sekolah Pascasarjana Institut Pertanian Bogor 